\title{
KNOWLEDGE OF CHILDREN AND YOUTH ABOUT FOREST FIRES: DISCREPANCIES BETWEEN BASIC PERCEPTION AND REALITY
}

\author{
Vladimir M. Cvetković \\ University of Belgrade, Faculty of Security Studies \\ Giulia Roder \\ University of Padova, Department of Land, Environment, \\ Agriculture and Forestry \\ Adem Öcal \\ Gazi University, Faculty of Education, Ankara, Turkey \\ Marina Filipović \\ University of Belgrade, Faculty of Security Studies \\ Bojan Janković \\ The Academy of Criminalistic and Police Studies, Belgrade, Serbia \\ Eric Noji \\ King Saud University, College of Medicine and University Hospitals, \\ Riyadh City, Kingdom of Saudi Arabia
}

Corests have a vital role for all living things. Children understanding of

forest phenomena is the important knowledge for various sectors such as educators, policymakers, environmentalists, etc. This paper deals with the factors that affect knowledge and perception of forest fires of students, aged 10 to 19, in the city of Belgrade. The research was conducted between October $20^{\text {th }}, 2013$ and February $3^{\text {rd }}, 2014$. The authors have used a method of surveying students in order to identify and describe the factors affecting their knowledge about forest fires. A total of 3,548 students from 18 schools in Belgrade participated in the survey. The results of the research show that there is a discrepancy between perception and reality that is what students think they know and what they actually know in very basic terms. This set of findings in combination with other findings of moderators replicates previous research on the need for educational programs to ensure there is a match between youth confidence about what they know of hazards and their actual knowledge levels. Mismatches between the two could have serious consequences in disaster risk reduction terms. Given basic knowledge gaps here, this translates into educational programming that then needs to take account of this basic discrepancy to ensure, even from the early ages, consistency between "knowledge and coping confidence" and actual knowledge and ability to cope and respond.

Key Words: disasters, forest fire, perception, Belgrade, children 


\section{Introduction}

In more recent times, forest ecosystems for livelihood of people are considered less

important than previously, especially in the most industrialized countries (Heino \& Karvonen, 2003). However, young people are typically more attuned to environmental issues compared to adults including considering forests essential for living, with additional benefits perceived in the social sphere (Genç \& Dem, 2010). Yet, these ecosystems are in danger of deforestation. Additionally, uncontrolled fires have been found to be on the rise in the last century all over the world (IPCC, 2007). Apart from material damage manifested in the destruction of timber and funds spent for reforestation, they also, of course, destroy lives and habitat in fire-affected areas (Choobineh, Ansari, \& Mohagheghi, 2015).Therefore, this topic is of interest to the scientific community and it is not limited to ecological and economic threats posed by these hazards, but it also focuses on environmental concerns including wildfire threats.

In fact, wildfires and human-wildfire interactions have been examined more extensively in recent years to understand relevant human behaviors including prevention, mitigation and preparedness actions. Specifically, there are several studies on stakeholders knowledge and perception in wildfire-prone areas (Doerr \& Santín, 2016; Gerald, 2010; Martin, Martin, \& Raish, 2011; Martinez-de Dios, Arrue, Ollero, Merino, \& GómezRodríguez, 2008; Ryan \& Hamin, 2008; Thapa, Cahyanto, Holland, \& Absher, 2013); on preparedness and evacuation (Martin, Bender, \& Raish, 2007; Mcneill, Dunlop, Heath, Skinner, \& Morrison, 2013); and on responses (Kulig et al., 2012). According to recent research (Finnis, Johnston, Ronan, \& White, 2010), public education campaigns mainly focus on adults awareness, knowledge and preparedness in relation to a range of natural hazards including forest fire and related environmental issues. The main thrust of this line of research is to evaluate enhancements in preparedness as a function of the increased awareness, knowledge and personalized concern.

By contrast, research on children and youth awareness, knowledge and opinions about fires is less forthcoming. However, the recent large-scale qualitative study (Towers, 2015) that included 26 focus groups with 87 8-12 year-old children and collateral interviews with 37 parents has demonstrated that children are quite capable of engaging in serious discussions about wildfires. ${ }^{1}$ At the same time, small research on wildfire education in school settings has been conducted. The research has demonstrated that schools can play a crucial role in household and local community readiness towards a possible hazardous situation (Ronan et al., 2016; Shaw, Shiwaku, \& Takeuchi, 2011).In other words, schools are not only agents for education of children and youth, they can help with "actionable knowledge" transfer to other members of household (Calik, 2013; Ronan et al., 2016) and community (Shaw et al., 2011). Of course, in order to ensure educational programming to be effective, it is necessary to have trained teachers that are confident of teaching hazardous events including wildfires. The research demonstrates that even in the face of nationally rolled out "ready to go" programs and resources in hazard education, teachers will report not feeling confident about teaching such programs or resources (e.g., fear of scaring children and youth) (Johnson, Ronan, Johnston, \& Peace, 2014).

\footnotetext{
${ }^{1}$ In the Australian context, where this research was conducted, fires in the wild are referred to as bushfires.
} 
In the Calik (2013) study, the emphasis was on senior science student teachers confidence in teaching such material, which showed that confidence could be increased and that such training is considered to be acceptable and feasible. Another finding of that study was that no educational programming can rely on science or technology "facts alone", but it is necessary to incorporate more human interface (e.g., built environment; psychosocial dimensions). Moreover, Barraza and Pineda (2003) found that secondary school students in forest communities in Mexico emphasized the value of integrating environmental issues to help give additional shape to young people wildfire awareness and knowledge. Beyond wildfires specifically and through analysis of textbooks used in educational programs in the Republic of Serbia, Milošević, Kovačević-Majkić and Panić (2012) argued that natural hazards and disasters are not more generally represented adequately, suggesting an educational profile of low concern towards this topic.

However, forest fires in Serbia have been on the rise since 2001 as a function of long and frequent heat waves interacting with human factors. The most extensive fires were in 2007 and 2012 burning respectively 17,500 ha and 2,150 ha of the mountain area with million euro damages (Dragićević, Milevski, Novković \& Milojković, 2010; Lukić et al., 2013). Forests in Serbia cover an area of 2,252,400 ha, representing $29.1 \%$ of the total area of the country. This percentage includes $27.6 \%$ of high forests, $64.7 \%$ of low (coppice) forests and $7.8 \%$ of forestry plantations. Furthermore, the total forest area in Serbia comprises $53 \%$ of state-owned forests, while the remaining $47 \%$ of forests belong to private forest owners (mostly 2-3 ha per forest owner) (Cvetković, Gačić \& Jakovljević, 2016).

Thus, on the basis of this backdrop, educating children and youth on forests including wildfires would be considered to be a useful conduit to better management generally, but, more specifically, to prevention and mitigation of forest fire risk. Thus, good understanding of children and youth awareness and knowledge about basic features of forest fires in Serbia can provide an important means to developing educational programs and teacher training about this topic. A working hypothesis in the current study is that many young people lack even some basic knowledge, but, at the same time, they have a perception what they should know. For example, in recent research done in Indonesia, most children $(71 \%)$ have been found to have a perception that they know what to do to be safe in disasters; however, $96 \%$ of these children have been found to have a low-medium level of actual knowledge (Amri, Bird, Ronan, Haynes, \& Towers, 2017). Similarly, here we have hypothesized that a large percentage of children would say they know what forest fire is, but that many of them, in fact, would not have even basic objective knowledge. We have also hypothesized that knowledge of very basic safety behaviors would also be lower. Receiving such information is quite important for developing hazard and disaster risk reduction and resilience educational programming including helping children differentiate between their perception and confidence and actual knowledge about hazards and their mitigation. In addition, the study also looked at perception and knowledge as a function of various demographic factors. Additional information has evaluated moderating factors including education achievement and youth educational modality preferences and outcomes as a function of modality exposure. 


\section{Method}

In order to evaluate factors that impact on child and youth knowledge about forest fires, we have developed a survey-based questionnaire described below. A large, multistage sample was recruited in eighteen schools in Belgrade City (Serbia) (Table 1). This research was conducted between October $20^{\text {th }}, 2013$ and March $02^{\text {nd }}, 2014$ involving 3,548 students aged 10-14 (M = 11.8; SD = .84) and $19(\mathrm{M}=16.07 ; \mathrm{SD}=1.24)$.

Survey instrument. The first part of the questionnaire captured demographic variables including age, gender, the employment of parents and their education level. Secondly, twenty questions were developed guided by previous research and theory (Eriksson, 2009; Johnson \& Miyanishi, 2001; Wisner \& Cluster, 2006), to investigate students awareness and basic knowledge, familiarity with basic safety procedures, emotional arousal (i.e. fear), risk perception/feelings of protection in school, education and information in relation to experiences with forest fires and other hazardous events. A pilot pretest was carried out with 50 students (25 male and 25 female) in "Saint Sava" School in Batočina to determine the appropriateness of questions and their level of understanding and comprehensibility. On the basis of the obtained results and feedback, the questionnaire has been then updated to improve readability and comprehensibility (e.g., more simple language used). The final questionnaire has a total of 29 items. The first 6 items are demographic and remaining 23 focus on hazard awareness, knowledge, education/discussions at school/home, information search, hazard exposure, hazard concerns/fears, perception of protection at school, motivation to learn about and participate in education related to disasters, a separate item on interest in training on emergency situations and preferred source(s) of information/education about natural hazards.

Table 1 - Sample of demographics by gender and school

\begin{tabular}{|c|c|c|c|c|c|}
\hline \multirow{3}{*}{ Name of school } & \multicolumn{3}{|c|}{ SAMPLE } & \multicolumn{2}{|c|}{ POPULATION } \\
\hline & \multicolumn{2}{|c|}{$\begin{array}{c}\text { Gender of students } \\
(\%)(\%)\end{array}$} & \multirow[t]{2}{*}{ Total } & \multicolumn{2}{|c|}{ Gender of students (\%) } \\
\hline & male & female & & male & female \\
\hline Mathematical Grammar School & 54.5 & 45.5 & 323 & 61 & 39 \\
\hline Law and Business School Belgrade & 29.8 & 70.2 & 242 & 25 & 75 \\
\hline Electrical Engineering High School „Nikola Tesla“ & 84.0 & 16.0 & 243 & 80 & 20 \\
\hline Agricultural High School & 35.3 & 64.7 & 150 & 29 & 71 \\
\hline Geodetic Technical School & 67.7 & 32.3 & 161 & 58 & 42 \\
\hline Medical High School „Nadežda Petrović” & 19.4 & 80.6 & 350 & 25 & 75 \\
\hline Geological and Hydrometeorological High School & 49.4 & 50.6 & 83 & 41 & 59 \\
\hline „Nada Dimić" Economics School & 38.0 & 62.0 & 50 & 27 & 73 \\
\hline High School of Tourism & 48.9 & 51.1 & 180 & 42 & 58 \\
\hline Sixth Belgrade Grammar School & 39.6 & 60.4 & 457 & 35 & 65 \\
\hline First Belgrade Grammar School & 36.1 & 63.9 & 379 & 44 & 56 \\
\hline Graphic High School & 40.2 & 59.8 & 92 & 30 & 70 \\
\hline Electrical Engineering High School „Stari grad“ & 94.4 & 5.65 & 342 & 85 & 15 \\
\hline Drinka Pavlović & 60 & 40 & 94 & 48 & 52 \\
\hline Borislav Pekić & 57 & 43 & 96 & 51 & 49 \\
\hline Duško Radović & 45 & 55 & 28 & 47 & 53 \\
\hline Ratko Mitrović & 61 & 39 & 54 & 43 & 57 \\
\hline Marko Orešković & 48 & 52 & 70 & 62 & 38 \\
\hline
\end{tabular}


Representativeness of the sample was checked in relation to the general student population of Belgrade. The outcomes revealed that the sample was representative of the larger school student population with the current sample of children and youth including $49.6 \%$ male and $50.4 \%$ female students compared to the population sample comprising $51.3 \%$ males and $48.7 \%$ females $(p>0.00)$. In terms of parents of sample participants, the largest percentage of them has completed secondary education ( $42.2 \%$ of mothers and $44 \%$ of fathers) followed by university graduates $(25.9 \%$ of mothers and $24.1 \%$ of fathers), higher education beyond (22.3\% of mothers and $21.6 \%$ of fathers) and, finally, those with postgraduate studies $(7.8 \%$ of mothers and $9.4 \%$ of fathers). With regard to the employment of students' parents, in $61.2 \%$ of cases both parents are employed, whereas in $32.6 \%$ of cases there is only one parent employed, while in $6.2 \%$ of cases both parents are unemployed (Table 2).

Table 2 - Demographic profile of other major sample variables

\begin{tabular}{llll}
\hline & & Frequency & Percentage (\%) \\
\hline \multirow{2}{*}{ Age } & $\leq 14$ & 196 & 6.4 \\
& $15-19$ & 2,867 & 93.6 \\
Employment of parents & Employed - one parent & 1,103 & 31.10 \\
& Employed - both parents & 2,244 & 63.20 \\
& Unemployed & 200 & 5.60 \\
& Primary school & 1.2 & 1.20 \\
Education of father & Secondary school & 41.3 & 41.60 \\
& High school & 21.6 & 21.80 \\
& University & 25.7 & 25.90 \\
& Postgraduate studies & 9.4 & 9.50 \\
Education of mother & Primary school & 2.0 & 2.00 \\
& Secondary school & 39.6 & 41.60 \\
& High school & 22.9 & 64.50 \\
& University & 27.7 & 92.20 \\
& Postgraduate studies & 7.8 & 100.00 \\
\hline
\end{tabular}

Results

In order to determine knowledge levels in relation to forest fires, respondents wereasked the following question: "Do you know what a forest fire is?" The analysis of descriptive statistical data showed that $95.6 \%$ of the participants responded yes, $2.5 \%$ no with $1.8 \%$ endorsing 'do not know'. On the other hand, in order to establish more objective knowledge of the respondents who answered that they know, they were then asked to choose from the following: uncontrolled combustion processes of forests $(63.2 \%$ - the correct answer), the process of the spread of fire smoke $(24.3 \%)$, process of burning grasses $(11.4 \%)$. In comparison to $95.6 \%$ of respondents who have answered that they know what a forest fire is, the results have supported our hypothesis and showed that objectively only $63.2 \%$ of respondents could endorse a more precise answer from a short list of three choices. Thus, $35.7 \%$ of respondents were wrong regarding more accurate knowledge. Clearly, if an open-ended question were posed, it is likely that fewer, perhaps much fewer than $63 \%$ could define/describe a forest fire with any precision. 
Moreover, we wanted to determine whether they know how to properly react in the case of forest fires through the following item: 'How would you react in the event that you are at risk of a forest fire?' The results have also supported the hypothesis and they were the following: shelter would be a safe place and call the fire department and rescue teams $(57 \%)$, would hide in the woods (17\%), I would ignore and continue on my way $(25 \%)$.

In terms of inferential findings and differences as a function of demographic factors, the results showed that there was a statistically significant relationship between gender and knowledge perception of forest fires $\left(x^{2}=24.77, \mathrm{df}=2, \mathrm{~V}=0.08\right)$ and knowledge of forest fires $\left(X^{2}=12.99\right.$, df $=2, V=0.06$ ) (see Table 3 ). More females $(97.3 \%$ ) answered that they know what a forest fire is compared to their male counterparts (93\%). Also, more females $(65.8 \%)$ gave correct answers when describing forest fire in more objective terms compared to males $(62.1 \%)$. Relatedly, more incorrect answers were given by male versus female students $(37.9 \%$ and $34.2 \%$ respectively).

There was no statistically significant relationship between gender and familiarity with safety procedures for responding to disasters caused by forest fires $\left(x^{2}=1.4\right.$, df $=2$, $V=0.02$ ). The relationship of age with knowledge or willingness to respond to forest fires represents a significant issue. The obtained results indicate that there was a statistically significant relationship between the age of the respondents and their familiarity with safety procedures for responding to disasters caused by forest fires $\left(x^{2}=12.5, \mathrm{df}=4, \mathrm{~V}=\right.$ 0.04 ). By contrast, there was no statistically significant relationship (see Table 3 ) between age and perception $\left(x^{2}=3.6, d f=4\right)$ or knowledge of forest fires $\left(x^{2}=3.7, d f=4\right)$. Nevertheless, while no statistical differences were found, there was a magnitude of differences across major age groups: most of the student (15-19) respondents $(59.3 \%)$ gave the correct answer to the question of what best described a forest fire compared to the 14 and under group (56.5\%). Equally, the most incorrect answers (43.5\%) were given by children respondents aged up to 14 compared to the $15-19$ year old group (41.7\%).

At the outset of the study, we thought that parent education level would influence the reduction of effects of disasters. While examining the connection between education levels of parents and their knowledge about forest fires, the results showed that there was a statistically significant relationship between children's fathers education level and perception $\left(x^{2}=76.3, d f=8, V=0.1\right)$, knowledge of forest fires $\left(x^{2}=31.7, d f=8, V=0.06\right)$ and familiarity with safety procedures $\left(X^{2}=29.4, d f=8, V=0.00\right) .97 .1 \%$ of the children whose fathers have undergraduate level higher education responded yes to what a forest fire is compared to $87.1 \%$ of those who did not. However, interestingly, $12.9 \%$ of children whose fathers have an academic title (i.e., Masters; PhD), answered as not knowing compared to $2.9 \%$ of those who did not. In terms of objective knowledge, most of the children (69.2\%), whose fathers are university graduates, gave the correct answer to the question of what best describes forest fires compared to $44.2 \%$ of those who did not. The largest number of incorrect answers (55.9\%) belongs to respondents whose fathers finished primary school compared to those who had higher educational background (38.9\%). Most respondents whose fathers are university graduates were familiar with safety procedures in case of forest fires $(64.4 \%)$ compared to those whose fathers finished primary school $(42.9 \%)$. Thus, these participants opted more often for an incorrect response. The results showed a statistically significant relationship between mothers education level and perception $\left(x^{2}=86.2, d f=8\right.$, $V=0.17)$, knowledge $\left(X^{2}=26.9, d f=8, V=0.06\right)$ and familiarity with safety procedures for responding to forest fires $\left(X^{2}=30.3, d f=8, V=0.06\right)$. Most of the respondents whose mothers 
have higher education (97\%) knew what a forest fire was compared to those who did not $(85.6 \%)$. Again, as with father data, $14.5 \%$ of participants whose mothers have academic titles (MSc; PhD) answered that they did not know compared to $3 \%$ of those who did not. Regarding knowledge about forest fires, most of the respondents $(70.1 \%)$ whose mothers are university graduates gave the correct answer to the question of what best describes forest fires compared to those who did not (54.9\%). The highest number of incorrect answers $(45.1 \%)$ was given by respondents whose mothers have primary education compared to those who had higher levels of education (29.9\%). Participants who were the most familiar with safety procedures in case of forest fires $(63.7 \%)$ were those whose mothers are university graduates compared to those who were not $(49.3 \%)$. Finally, the majority $(50.7 \%)$ of respondents whose mothers have primary school education endorsed an inadequate procedure compared to those with higher levels of education (36.3\%). The situation here reveals the same pattern as with fathers. The children with parents of higher levels of education also have more objective safety knowledge.

Table 3 - Analyses between demographic variables and study subjects

\begin{tabular}{|c|c|c|c|c|c|}
\hline \multicolumn{2}{|r|}{ Research variables } & \multirow{2}{*}{$\begin{array}{l}\text { Value } \\
24.77\end{array}$} & \multirow{2}{*}{$\begin{array}{l}\mathrm{df} \\
2\end{array}$} & \multirow{2}{*}{$\begin{array}{r}\begin{array}{l}\text { Asymp. Sig. } \\
\text { (2-sided) }\end{array} \\
.000^{*}\end{array}$} & \multirow{2}{*}{$\begin{array}{c}\text { Cramer's V } \\
.084\end{array}$} \\
\hline & Perception of forest fires & & & & \\
\hline \multirow[t]{3}{*}{ Gender } & Knowledge of forest fires & 12.99 & 2 & $.002^{*}$ & .061 \\
\hline & Familiarity with safety procedures & 1.41 & 2 & .493 & .020 \\
\hline & Perception of forest fires & 3.63 & 4 & .459 & .023 \\
\hline \multirow[t]{3}{*}{ Age } & Knowledge of forest fires & 3.73 & 4 & .444 & .023 \\
\hline & Familiarity with safety procedures & 12.52 & 4 & $.014^{*}$ & .042 \\
\hline & Perception of forest fires & 76.32 & 8 & $.000^{*}$ & .104 \\
\hline \multirow[t]{3}{*}{ Fathers education } & Knowledge of forest fires & 31.70 & 8 & $.000^{*}$ & .067 \\
\hline & Familiarity with safety procedures & 29.47 & 8 & $.000^{*}$ & .065 \\
\hline & Perception of forest fires & 86.26 & 8 & $.000^{*}$ & .110 \\
\hline \multirow[t]{3}{*}{ Mothers education } & Knowledge of forest fires & 26.96 & 8 & $.001^{*}$ & .062 \\
\hline & Familiarity with safety procedures & 30.33 & 8 & $.000^{*}$ & .066 \\
\hline & Perception of forest fires & 14.43 & 4 & $.006^{*}$ & .045 \\
\hline \multirow[t]{2}{*}{ Success in school } & Knowledge of forest fires & 69.98 & 4 & $.000^{*}$ & .100 \\
\hline & Familiarity with safety procedures & 76.42 & 4 & $.000^{*}$ & .105 \\
\hline \multirow{4}{*}{$\begin{array}{l}\text { Employment of } \\
\text { parents }\end{array}$} & Perception of forest fires & 22.02 & 4 & $.000^{*}$ & .056 \\
\hline & Knowledge of forest fires & 6.80 & 4 & .147 & .031 \\
\hline & Familiarity with safety procedures & 11.61 & 4 & $.020^{*}$ & .041 \\
\hline & Perception of forest fires & 4.34 & 2 & .114 & .035 \\
\hline \multirow[t]{3}{*}{ Education in family } & Knowledge of forest fires & 8.91 & 2 & $.012^{*}$ & .050 \\
\hline & Familiarity with safety procedures & 9.07 & 2 & $.011^{*}$ & .051 \\
\hline & Perception of forest fires & 15.10 & 2 & $.001^{*}$ & .065 \\
\hline \multirow[t]{2}{*}{ Education in school } & Knowledge of forest fires & 1.65 & 2 & .439 & .022 \\
\hline & Familiarity with safety procedures & 12.27 & 2 & $.002^{*}$ & .059 \\
\hline
\end{tabular}

*The difference is significant at the 0.05 level.

The results showed that there was a statistically significant relationship between success in school based on self-reported school rating (successful versus average) and perception $\left(x^{2}=14.4, d f=4, V=0.04\right)$, knowledge $\left(x^{2}=69.9 \mathrm{df}=4, V=0.1\right)$ and familiarity with safety procedures for responding to disasters caused by forest fires $\left(X^{2}=76.4, \mathrm{df}=4, V=0.1\right) .71 .6 \%$ of 
the participants who were excellent (5) in school knew how to describe forest fires compared to those who reported basic success (enough success, 2) $(46.7 \%)$. By contrast, $45.9 \%$ of the respondents who reported a good level of success (3) gave incorrect answers compared to those who reported very good success (4) $(59.9 \%)$. Most of the respondents $(63.6 \%)$ who had excellent success in school showed familiarity with safety procedures in case of forest fires compared to those with enough success $(46.7 \%)$, whereas $53.4 \%$ of respondents with enough success marked an incorrect answer (compared to $36.4 \%$ of those who reported excellent school success).

As seen in Table 3, there was a statistically significant relationship between parents employment and perception $\left(x^{2}=22.1, \mathrm{df}=4, V=0.05\right)$ and familiarity with safety procedures for reacting in case of disasters and forest fires $\left(x^{2}=11.6, d f=4, V=0.04\right)$. On the other hand, there was no statistically significant relationship between parents employment and knowledge about forest fires $\left(X^{2}=6.8, d f=4, V=0.03\right)$. Most of the respondents $(96 \%)$, whose parents are employed endorsed that they knew what a forest fire was compared to $91 \%$ of those whose parents were not employed. The respondents $(59.2 \%)$ whose parents are employed marked the proper procedure (compared to $52 \%$ ), while the $47.4 \%$ of respondents with unemployed parents indicated an inadequate procedure in case of forest fires (compared to $40.8 \%$ of those who were employed). From the presented data, it can be seen that respondents whose parents are unemployed provided the largest number of incorrect answers and those with employed parents the greatest number of correct answers.

According to the results, there was a statistically significant relationship between education in school about dangers of forest fires and their perception $\left(x^{2}=15.1, d f=2\right.$, $V=0.06)$ and familiarity with safety procedures $\left(x^{2}=12.2, d f=2, V=0.02\right)$. On the other hand, there was no statistically significant relationship between education in schools about the dangers of forest fires and their knowledge $\left(x^{2}=1.6, d f=2\right)$. Most of the respondents $(96.3 \%)$ were familiar with forest fires due to their school education compared to $94.5 \%$ of those who were not familiar due to their school education. Relatedly, more incorrect answers (5.5) were given by those who were not familiar due to their school education versus those who were familiar with forest fires due to their school education. In terms of safety procedures, more children exposed to education $(58 \%)$ knew the correct safety procedure versus those who were not exposed (52\%) (Figure 1).

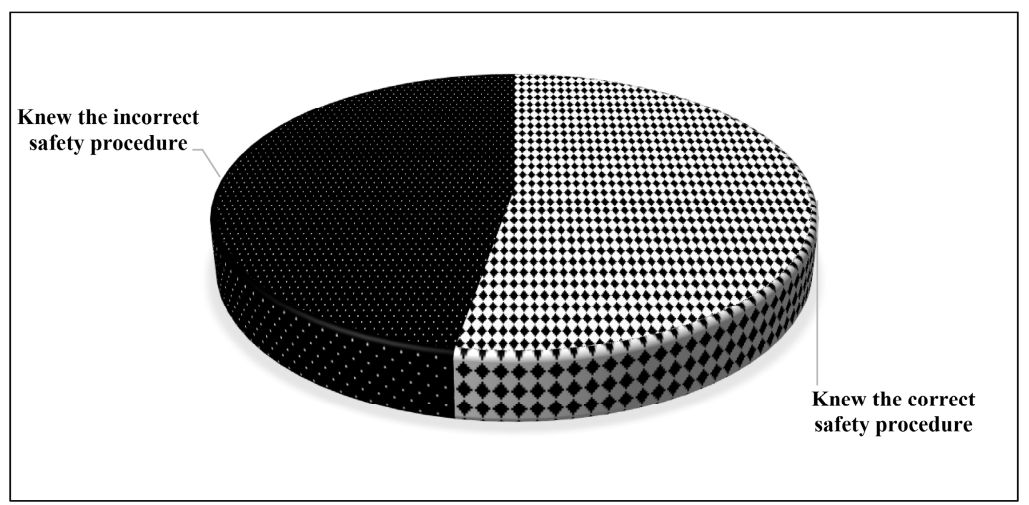

Figure 1 - Percentage distribution of safety procedure knowledge of children exposed to school education 
In this study, there was a statistically significant relationship between respondents who learned about forest fires in family and knowledge $\left(X^{2}=15.1, d f=2, V=0.05\right)$ and familiarity with safety procedures $\left(x^{2}=15.1, d f=2, V=0.05\right)$. In contrast, there was no relationship between respondents who learned about disasters in family and perception $\left(x^{2}=15.1, d f=2\right)$. Most of the respondents $(93.8 \%)$, who were informed within their family, answered that they knew compared to $90 \%$ of those who were not were informed within their family. More incorrect answers (10\%) were given by those who were not informed within their family compared to $6.2 \%$ who were informed within their family. In terms of safety procedures, more children exposed to family learning $(60 \%)$ knew the correct safety procedure versus those who were not exposed $(54 \%)$ (Figure 2).

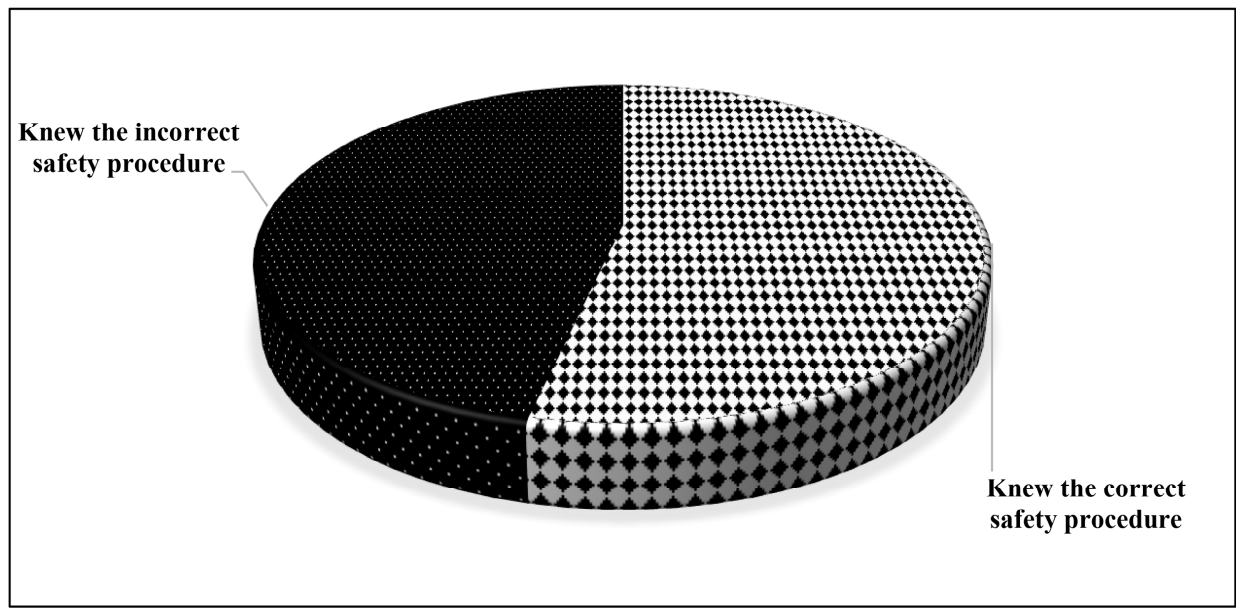

Figure 2 - Percentage distribution of safety procedure knowledge of children exposed to family learning

In their study, Kurita et al. (2006) found that audiovisual methods of dissemination of the knowledge about tsunamis are the most effective means. Also, they specifically pointed out that students gained more knowledge with the help of the media. These findings have been confirmed by this survey. By examining preferences of students for the manner in which they would like to learn more about wildfires it was found that $57.1 \%$ of respondents wanted to watch educational films and series; $33.1 \%$ wanted to participate in workshops; $21.7 \%$ wanted more classical classroom lessons; $20.2 \%$ wanted interesting video games; and $17.1 \%$ would like to learn through case studies.

The perception of forest fires was found to be related to the way of gaining information about disasters such as classical lessons, television, internet and interesting video games except radio. As seen in Table 4, significant differences have emerged as a function of exposure to a learning modality and perception, objective knowledge and safety 
procedure knowledge. Here we have summarized group differences that were of the greatest magnitude (with other differences available from the authors). Perhaps reflecting more interest in video learning, most of the respondents $(85.8 \%)$, who reported being informed by television answered that they knew compared to $74 \%$ of those who were not informed by television. Differences as a function of other modalities were minimal. For example, most of the respondents $(97.5 \%)$, who were informed by classical classroom lessons answered that they knew compared to $(95 \%)$ of those who were not informed in the same manner.

Objective knowledge of forest fires was also found to be related to television watching $(65.2 \%$ television watching versus $57.1 \%$ non-television watching) and classroom lessons (69.7\% correct versus $61.9 \%$ not exposed to classroom lessons). In terms of safety procedures, the greatest differences were found in a function of internet learning $(69 \%$ versus $57.1 \%)$ and classroom lessons $(69.7 \%$ versus $61.9 \%$ respectively).

Table 4 - Analyses between way of gaining information and study subjects

\begin{tabular}{|c|c|c|c|c|c|}
\hline \multicolumn{2}{|c|}{ Research variables } & \multirow{2}{*}{$\begin{array}{l}\text { Value } \\
10.13\end{array}$} & \multirow{2}{*}{$\begin{array}{l}\mathrm{df} \\
2\end{array}$} & \multirow{2}{*}{$\begin{array}{r}\begin{array}{c}\text { Asymp. Sig. } \\
\text { (2-sided) }\end{array} \\
.006^{*}\end{array}$} & \multirow{2}{*}{$\begin{array}{c}\begin{array}{c}\text { Cramer's } \\
\text { V }\end{array} \\
.054\end{array}$} \\
\hline Classical lessons & Perception of forest fires & & & & \\
\hline & Knowledge of forest fires & 18.78 & 2 & $.000^{*}$ & .073 \\
\hline & $\begin{array}{l}\text { Familiarity with safety proce- } \\
\text { dures }\end{array}$ & 22.16 & 2 & $.000^{*}$ & .080 \\
\hline \multirow[t]{3}{*}{ Television } & Perception of forest fires & 121.80 & 2 & $.000^{*}$ & .185 \\
\hline & Knowledge of forest fires & 28.05 & 2 & $.000^{*}$ & .089 \\
\hline & $\begin{array}{l}\text { Familiarity with safety proce- } \\
\text { dures }\end{array}$ & 2.39 & 2 & .302 & .026 \\
\hline \multirow[t]{3}{*}{ Radio } & Perception of forest fires & .975 & 2 & .614 & .017 \\
\hline & Knowledge of forest fires & 1.34 & 2 & .510 & .020 \\
\hline & $\begin{array}{l}\text { Familiarity with safety proce- } \\
\text { dures }\end{array}$ & 9.29 & 2 & .010 & .052 \\
\hline \multirow[t]{3}{*}{ Internet } & Perception of forest fires & 30.58 & 2 & $.000^{*}$ & .093 \\
\hline & Knowledge of forest fires & 52.62 & 2 & $.000^{*}$ & .123 \\
\hline & $\begin{array}{l}\text { Familiarity with safety proce- } \\
\text { dures }\end{array}$ & 13.25 & 2 & $.001^{*}$ & .062 \\
\hline \multirow{3}{*}{$\begin{array}{l}\text { Interesting video } \\
\text { games }\end{array}$} & Perception of forest fires & 27.19 & 2 & $.000^{*}$ & .088 \\
\hline & Knowledge of forest fires & 11.89 & 2 & $.003^{*}$ & .058 \\
\hline & $\begin{array}{l}\text { Familiarity with safety proce- } \\
\text { dures }\end{array}$ & 6.90 & 2 & $.032^{*}$ & .044 \\
\hline
\end{tabular}

*The difference is significant at the 0.05 level. 


\section{Discussion}

The current study has been designed to examine some important basics related to knowledge of forest fires in a large sample of the Serbian youth. The main findings here that perception of hazard-related knowledge does not equate to actual knowledge replicate recent research in Indonesia (Amri et al., 2017) done in an older age cohort in a different country. Here, a very large percentage, nearly $100 \%$, perceived they knew what a forest fire was. However, the findings showed a significant discrepancy between this perception and objective knowledge. In addition, the knowledge of basic safety procedures had also much lower percentage of correct responses including a number of demographic factors analyses. In fact, these discrepancies could be seen across items that were quite basic multiple choice responses. In our opinion, if students had been asked more open-ended questions about forest fire characteristics and safety procedures, it might well have happened that the discrepancies would be even greater, perhaps much greater. This set of findings is in favor of the argument that asking children about their knowledge perception, or, to put it slightly differently, their confidence in their knowledge is not sufficient. The research, which has been done mainly with adult samples points to the role of confidence or efficacy in facilitating disaster risk reduction knowledge and preparedness (e.g., Paton, Smith, \& Johnson, 2005). However, at the same time, the same research points out that no single feature is a predictor on its own and needs to be coupled with a number of known facilitators. In addition to this idea, this emerging set of findings helps understand that children and youth may misperceive their level of knowledge and, while they may feel more confident as a result, this may actually be more of false confidence not matched to actual knowledge of hazards and what needs to be done to reduce risks. Both this study and the Indonesian one demonstrate that children may have quite a significant mismatch in their belief in their knowledge and actually having that knowledge. Thus, future research examining such a mismatch might look into ways to reduce it and whether "mismatched" versus "matched" samples have better risk reduction and resilience outcomes.

In addition to the main findings, additional findings showed there were factors that moderated responses in perception and knowledge items. However, in general, there was no moderating factor to reduce significantly the mismatch between knowledge perception and actual knowledge. Nevertheless, the findings here do point to some moderating factors that appear to be useful in assisting the youth to acquire basic knowledge including demographic factors and educational modality. Taking these findings into account, they point to the ways in which education programs might be carried out. For example, young people who are older and more successful in school and then perhaps more knowledgeable about hazard-related risk reduction might serve as peer tutors for younger children and the youth. Moreover, the findings provide support to infuse DRR education approaches (e.g., Ronan \& Towers, 2014) through the inclusion of a range of learning modalities that also match the youth preferences (e.g., use of video; Kurita et al., 2006), are interactive and participatory (e.g., video games supplemented with skillsfocused practice; UNESCO/UNICEF, 2013), and supplement traditional classroom learning. For example, in our program of research in Australia, we have developed a video game on school drills that can be played, but it also serves as an accompaniment to 
classroom learning and actual drilling practice. In the case of school drills, such combinations could then be used to overcome problems that the research has identified including the fact that rote drilling procedures may not effectively reduce risks in the manner thought (Johnson, Johnston, Ronan, \& Peace, 2014).

Shiwaku et al. [47] points out that school lessons about disasters typically raise awareness of risks, but they currently do not help children learn and carry out preventive measures effectively. The survey conducted by Becker et al. [18] indicates that traditional educational approach in which students receive passive information about disasters results in a very low level of awareness and motivation for readiness. Thus, the findings here can be thought of as contributing to the idea of more active learning and skillsbuilding modalities including active peer learning strategies and other means.

In their study, Kurita et al. [20] found that audiovisual methods of dissemination of the knowledge about tsunamis are the most effective means of transfer. Also, they specifically pointed out that students gained more knowledge with the help of the media. These findings have been confirmed here. By examining preferences of students for the manner in which they would like to learn more about disasters, it was found that the largest percentage $(57.1 \%)$ preferred these means compared to other modalities, where a minority of participants showed preference.

The limitations in this study include the fact that basic perception and knowledge have been used. Thus, future research might expand the range of knowledge and skillsfocused items including behavioral assessment, to learn more about possible discrepancies between perception and actual knowledge and skills. By the same token, while items were basic, they revealed in a large sample very basic knowledge/recognition memory gaps and discrepancies between what students think they know and what they actually know.

\section{Conclusion}

Education about forest fires and other hazards in schools is most often linked to classroom-based knowledge including familiarity with key safety procedures (Ronan et al., 2016). Educational programs that go beyond this and include knowledge, attitude and skills for forest fires, while capitalizing on children and youth learning preferences and motivation to be active participants (e.g., through peer learning strategies), are likely to have enhanced DRR and resilience outcomes.

The presented results are important for proper initial framing of prevention programs aimed at educating young people about the dangers inherent in forest fires in such a way that any confidence derived as a function of education program participation is matched to their knowledge and abilities to actually keep them safe. Therefore, it is necessary to strengthen the traditional forms of knowledge transfer and to find a way to convey educational content to them through innovative, active learning and participatory means. It is clear that the next steps in education on the topic of forest fires must be based on the new standards. The problem should be solved using a long-term approach with the aim to get as many young people as possible to be educated about the dangers of forest fires and the necessary safety procedures for them to be able to respond adequately. 


\section{References}

[1] Amri, A., Bird, D. K., Ronan, K., Haynes, K., \& Towers, B. (2017). Disaster risk reduction education in Indonesia: challenges and recommendations for scaling up. Natural Hazards and Earth System Sciences, 17(4), 595.

[2] Barraza, L., \& Pineda, J. (2003). How young people see forests in Mexico: a compararison of two rural communities. Unasylva, 54(213), 10-17.

[3] Calik, M. (2013). Effect of Technology-Embedded Scientific Inquiry on Senior Science Student Teachers' Self-Efficacy. EURASIA Journal of Mathematics, Science \& Technology Education, 9(3), 223-232.

[4] Choobineh, M., Ansari, B., \& Mohagheghi, S. (2015). Vulnerability assessment of the power grid against progressing wildfires. Fire Safety Journal, 73, 20-28.

https://doi.org/10.1016/j.firesaf.2015.02.006

[5] Cvetković, V., Gačić, J., \& Jakovljević, V. (2016). Geospatial and temporal distribution of wildfires. Vojno delo, 2/2016, 108-127.

[6] Doerr, S. H., \& Santín, C. (2016). Global trends in wildfire and its impacts: perceptions versus realities in a changing world. Philosophical Transactions of the Royal Society of London. Series B, Biological Sciences, 371(1696), 281-329. https://doi.org/10.1098/rstb.2015.0345.

[7] Dragicevic, S., Milevski, I., Novkovic, I., \& Milojkovic, B. (2010). The natural conditions as a limiting factor for the development of Serbian-Macedonian border area. Glasnik Srpskog Geografskog Dru?tva, 90(4), 29-44. https://doi.org/10.2298/GSGD1004029D

[8] Erdogan, M., \& Marcinkowski, T. (2015). Development and validation of children's environmental affect (attitude, sensitivity and willingness to take action) scale. Eurasia Journal of Mathematics, Science and Technology Education, 11(3), 577-588.

https://doi.org/10.12973/eurasia.2015.1347a

[9] Eriksson, K. (2009). Knowledge transfer between preparedness and emergency response: a case study. Disaster Prevention and Management, 18(2), 162-169. doi:10.1108/09653560910953234

[10] Finnis, K. K., Johnston, D. M., Ronan, K. R., \& White, J. D. (2010). Hazard perceptions and preparedness of Taranaki youth. Disaster Prevention and Management, 19(2), 175-184. https://doi.org/10.1108/09653561011037986

[11] Genç, H., \& Dem, H. (2010). İ lkö ğ retim yedinci s I n I fö ğ rencilerinin orman kavram ı n । alg I lamalar I: fenomenografik bir ara ş $t$ । rma Seventh grade primary school students ' understanding of forest : a phenomenographic study, 34-48.

[12] Gerald, C. A. (2010). Public Perception of Wildfire Risk and Prescribed Burning in the Wildland/Urban Interface of the Louisiana Florida Parishes. Retrieved from http://etd.Isu.edu/docs/available/etd-11172010-151513/unrestricted/Gerald_Thesis.pdf

[13] Heino, J., \& Karvonen, J. (2003). Forests - An integrated part of Finnish life. Unasylva, 54(213), 3-9.

[14] IPCC. (2007). Climate Change 2007: Impacts, Adaptation and Vulnerability. Contribution of Working Group II to the Fourth Assessment Report of the Intergovernmental Panel on Climate 
Change. (M. Parry, O. Canziani, J. Palutikof, P. van der Linden, \& C. Hanson, Eds.), IPCC. Cambridge University Press.

[15] Johnson, E. A., \& Miyanishi, K. (2001). Forest fires: behavior and ecological effects (Vol. 593): Academic Press San Diego, CA.

[16] Kulig, J. C., Botey, A. P., Townshend, I., Awosaga, O., Shepard, B., Edge, D., ... Lightfoot, N. (2012). Families and Children: Responses to Wildfires-Links to Community Resiliency. University of Lethbridge Publications, 1-31. Retrieved from www.ruralfire.ca

[17] Kurita, T., Nakamura, A., Kodama, M., \& Colombage, S. R. (2006). Tsunami public awareness and the disaster management system of Sri Lanka. Disaster Prevention and Management: An International Journal, 15(1), 92-110.

[18] Lukić, T., Gavrilov, M. B., Marković, S. B., Komac, B., Zorn, M., Mlađan, D., ... Prentović, R. (2013). Classification of disasters between the legislation and application: experience of the Republic of Serbia. Acta Geographica Slovenica, 53(1), 149-164.

https://doi.org/10.3986/AGS53301

[19] Martin, I. M., Bender, H., \& Raish, C. (2007). What motivates individuals to protect themselves from risks: The case of wildland fires. Risk Analysis, 27(4), 887-900. https://doi.org/10.1111/j.1539-6924.2007.00930.x

[20] Martin, I. M., Martin, W. E., \& Raish, C. B. (2011). A qualitative and quantitative analysis of risk perception and treatment options as related to wildfires in the USDA FS Region 3 National Forests. USDA, Forest Service General Technical Report RMRS-GTR-260, Rocky Mountain Research Station, (September), 57. Retrieved from http://www.treesearch.fs.fed.us/pubs/38763\%5Cnhttp://www.fs.fed.us/rm/pubs/rmrs_gtr260.pdf

[21] Martinez-de Dios, J. R., Arrue, B. C., Ollero, A., Merino, L., \& Gómez-Rodríguez, F. (2008). Computer vision techniques for forest fire perception. Image and Vision Computing, 26(4), 550-562. https://doi.org/10.1016/j.imavis.2007.07.002

[22] Mcneill, I. M., Dunlop, P. D., Heath, J. B., Skinner, T. C., \& Morrison, D. L. (2013). Expecting the unexpected: Predicting physiological and psychological wildfire preparedness from perceived risk, responsibility, and obstacles. Risk Analysis, 33(10), 1829-1843. https://doi.org/10.1111/risa.12037

[23] Milošević, V., Kovačević-Majkić, J., \& Panić, M. (2012). Prirodne nepogode i nastava geografije u Srbiji - trenutno stanje. Zbornik Radova Sa Naučnog Skupa: Problemi I Izazovi Savremene Geografske Nauke I Nastave, 161-167.

[24] Preparedness education in New Zealand primary schools", Disaster Prevention and Management, Vol. 23 Iss 4 pp. $370-380$.

[25] Ronan, K. R., Haynes, K., Towers, B., Alisic, E., Ireland, N., Amri, A., Davie, S., \& Petal, M. (2016). Child-centred disaster risk reduction: Can disaster resilience programs reduce risk and increase the resilience of children and households? Australian Journal of Emergency Management, 31, 49-58.

[26] Ryan, R. L., \& Hamin, E. (2008). Wildfires, Communities, and Agencies: Stakeholders' Perceptions of Postfire Forest Restoration and Rehabilitation. Journal of Forestry, 106(7), 370-379.

[27] Shaw, R., K. Shiwaku and Y. Takeuchi. 2011. Disaster Education. Bingley, UK: Emerald. 
[28] Thapa, B., Cahyanto, I., Holland, S. M., \& Absher, J. D. (2013). Wildfires and tourist behaviors in Florida. Tourism Management, 36, 284e292.

https://doi.org/10.1016/j.tourman.2012.10.011

[29] Victoria A. Johnson Kevin R. Ronan David M. Johnston Robin Peace, (2014), "Implementing disaster

[30] Wisner, B., \& Cluster, T. (2006). Let our children teach us!: A review of the role of education and knowledge in disaster risk reduction: Books for Change. 